\title{
Daily Dispersals from Resting Sites of the Giant African Snail, Achatina fulica (Férussac) (Pulmonata; Achatinidae), on a North Pacific Island
}

\author{
Kiyonori TоміYAMA Department of Earth and Environmental Sciences, Faculty of Science, Kagoshima \\ University, Korimoto, Kagoshima 890-0065, Japan
}

\begin{abstract}
Daily movement of the giant African snail Achatina fulica was studied. This snail is nocturnal and in the daytime prefers to rest in shrubs, often along the forest edge. The density was low in primary or secondary forests. The cumulative distance of movements of young adults was longer than that of old adults. They forage and mate in open fields. This behavior is likely to be a cause of serious damages to field crops cultivated next to the forest.
\end{abstract}

Key words: Achatina / giant African snail / radio tracking / circadian rhythm / mollusca

The giant African snail, Achatina fulica, is one of the most destructive molluscan pests in many tropical or subtropical areas. The damage to crops by snails is most serious in farms that stand close to forests (Mead, 1979). Snails hide in the forest in daytime and come out to feed on crops in the field at night. Aoki (1978) reported that $A$. fulica is widely distributed in areas affected by humans, but is relatively rare in undisturbed forests in subtropical areas. Other studies reported that $A$. fulica prefers disturbed areas such as a plantation, village, or forest edge rather than a natural forest (Mead, 1979; Lake and O'Dowd, 1991; Muniappan et al., 1986; Strugeon, 1971; Upatham et al., 1988).

Many observations have shown that $A$. fulica rest in bushes between forests and fields in daytime and crawl out to the open fields at night (Mead, 1961,1979; Sturgeon, 1971). Lake and O'Dowd (1991) suggested that predation pressure of red crabs, Gecarcoidea natalis which inhabits rain forest has reduced the density of $A$. fulica in the natural forest on Christmas island. However, this observation does not apply to all areas where $A$. fulica has been introduced. In some regions an influential predator dose not seem to occur in the forest, although $A$. fulica is virtually absent in natural forest but abundant in disturbed areas. There have been few studies on the patterns of their daily activity in areas close to the forest edge.

The objectives of this study are to determine the resting site of $A$. fulica and to detect possible differences in dispersal pattern between young and old adults, by means of radio tracking.

\section{MATERIALS AND METHODS}

\section{Study site}

This study was conducted in the northern part of Chichi-jima Island in the Ogasawara (Bonin) Islands located in North Pacific Ocean at $27^{\circ} \mathrm{N}-142^{\circ} \mathrm{E}$. This site provides a vegetational pattern that is useful 
to examine relationships between dispersal and vegetation. The vegetation near the road running along the forest edge changed vertically to the road edge between the forest and road. The grass field next to the road side was dominated by and ended at about $1.5 \mathrm{~m}$ from the road. Shrubs out the side grassfield were composed of mainly Leucaena leucocephala in the width of $2.5 \mathrm{~m}$. Beyond the shrubs, secondary forests dominated by Schima wallichii extended over $100 \mathrm{~m}$ in width. Pinus luchuensis and Planchonella obovata were also commonly found in these forests.

\section{Observation of density distribution}

To investigate the density distribution of $A$. fulica, an area of $16 \mathrm{~m}$ long and $5 \mathrm{~m}$ wide was settled along the road. This area was divided into 160 plots of $1 \mathrm{~m} \sim 0.5 \mathrm{~m}$ each. The number of individuals in each plot was recorded on four occasions: at 1:00 p.m. and 11:00 p.m., 5 July, 1987 to compare their distributions between daytime and nighttime, and at 1:00 p.m., 19 and 21 July, 1987 to compare their distributions on fine and rainy days, respectively.

\section{Radio-tracking}

Radio tracking was used to trace the movement patterns of $A$. fulica in the area described above.

The shell of $A$. fulica continues to grow some months after the reproductive organs are fully formed (Kondo, 1964; Tomiyama, 1993). The thickness of peristome lip is usually very thin while the shell is growing. Calcium deposition on the inner surface of shell continues thereafter, and the peristome becomes thick. The peristome thickness would be an index useful for judging their shell growth (Tomiyama, 1993). In this study, matured snails which have developed genital atria were divided into two categories according to peristome thickness: young adults with peristome less than $0.5 \mathrm{~mm}$ thick and old adult with peristome thicker than about $0.8 \mathrm{~mm}$. Snails typical of those two categories were chosen for the experiment.

Eight waterproof radio-transmitters were prepared. Each includes a quartz crystal with a frequency between 52.700 and $53.000 \mathrm{MHz}$, and a silver oxide battery. The size of the entire transmitter is about $25 \sim 10 \sim 5 \mathrm{~mm}$, and weighs about $3.0 \mathrm{~g}$ which is $5-10 \%$ of body weight of each snail. It has a transmitting antenna of stainless steel wire which is $0.5 \mathrm{~mm}$ in diameter, and $17 \mathrm{~cm}$ long, and coated with vinyl. The longevity of battery was about 1 month. The maximum range for detecting a signal was $500 \mathrm{~m}$ in radius. The transmitter was attached on each of the shells of 4 young adults and 4 old adults with a small amount of epoxy-bond.

The experiment was carried out from 16th to 26th July, 1989. The locations of animals were usually determined once a day at 9:00 a.m. to estimate the dispersal distance per day. A multiple channel receiver YAESU FT-690 (about $1.2 \mathrm{~kg}$ ) was used to monitor the signals from radio-transmitters. The receiver was first connected to a quarter wavelength Yagi antenna to estimate approximate location of snails. Then the antenna was exchanged with a small loop antenna $(12 \mathrm{~cm}$ diameter) to determine the precise position. The position was finally confirmed visually and mapped to the nearest $5 \mathrm{~cm}$.

\section{RESULTS}

\section{Distribution pattern}

Figure $1 \mathrm{~A}$ and $1 \mathrm{~B}$ show density distribution of $A$. fulica at 13:00 and 23:00, 5 July, 1987, respectively. 

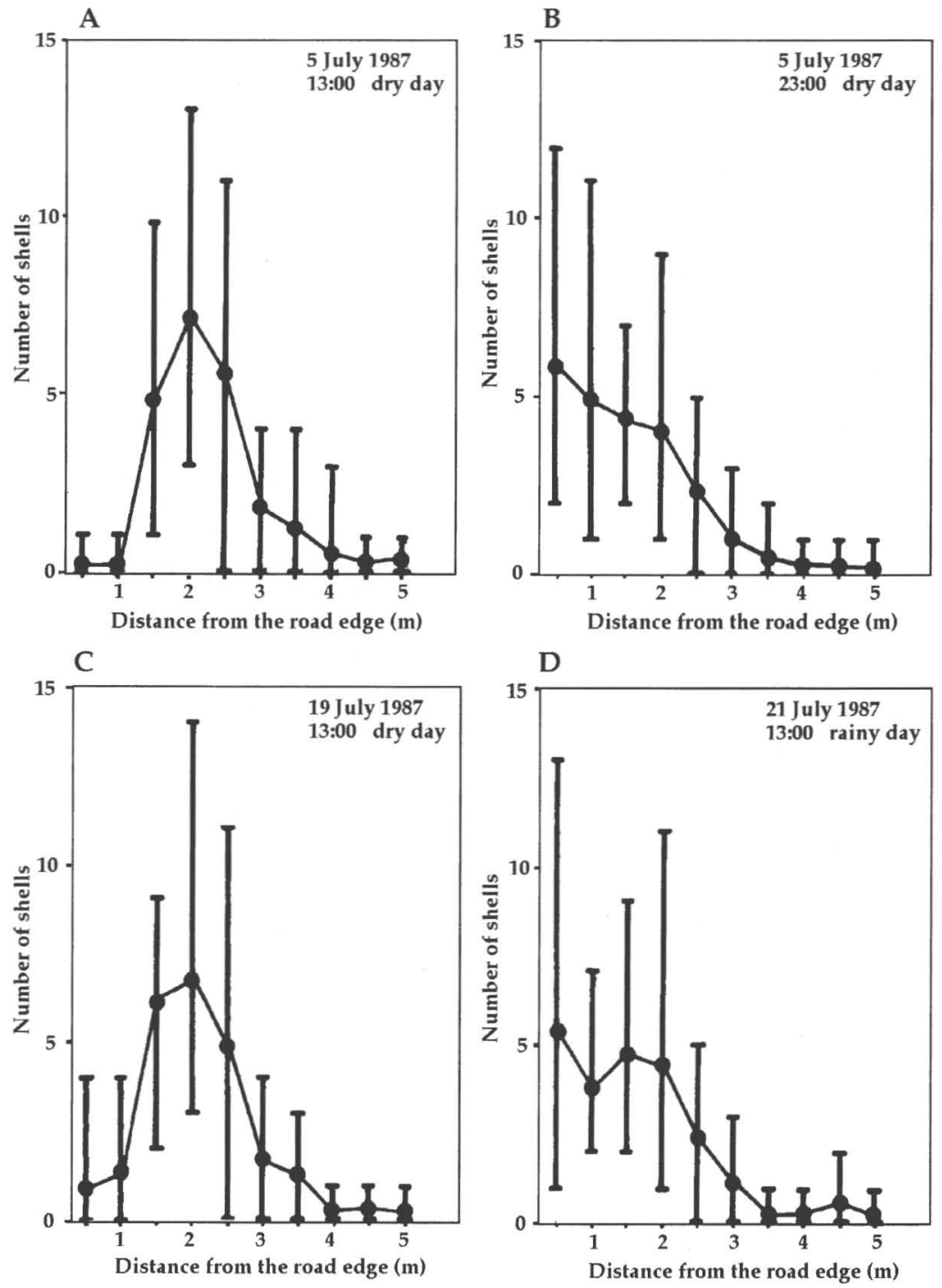

Fig. 1. Density distribution of Achatina fulica from the road to forest. Solid circles indicate the mean density in 16 plots $(1 \mathrm{~m} \times 0.5 \mathrm{~m})$ along the road. Vertical lines indicate the ranges of density. A; 1:00 p.m., 5 July, 1987. dry. B; 11:00p.m., 5 July, 1987. dry. C; 1:00 p.m., 19 July, 1987. dry. D; 1:00 p.m., 21 July, 1987. wet.

In the daytime their density was relatively high 1.5 to $2.5 \mathrm{~m}$ from the road edge, corresponding to the shrub zone. After 10 hours at night their density increased in the grassland away from the shrubs, especially near the road side. These results show that in the daytime the snails are associated with scrub close to the forest edge. Every animal observed in the daytime was resting under the litter. However, they moved to the grassland from the scrub 2 to 3 hours after the sunset. Their foraging and copulation were usually observed in this open area at night. Many snails were found off the grass area dispersing on the road. Some of them were crushed by cars or dried up due to the sunlight. 


\section{Young - adults}
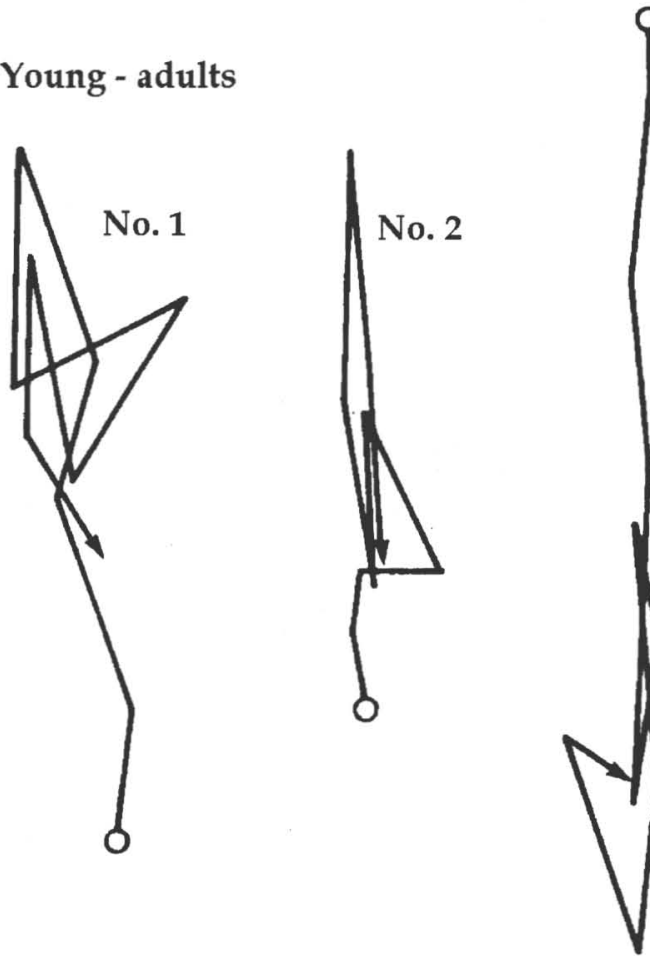

No. 3 No. 4

\section{Old - adults}

No. 5

No. 6

No. 7

No. 8
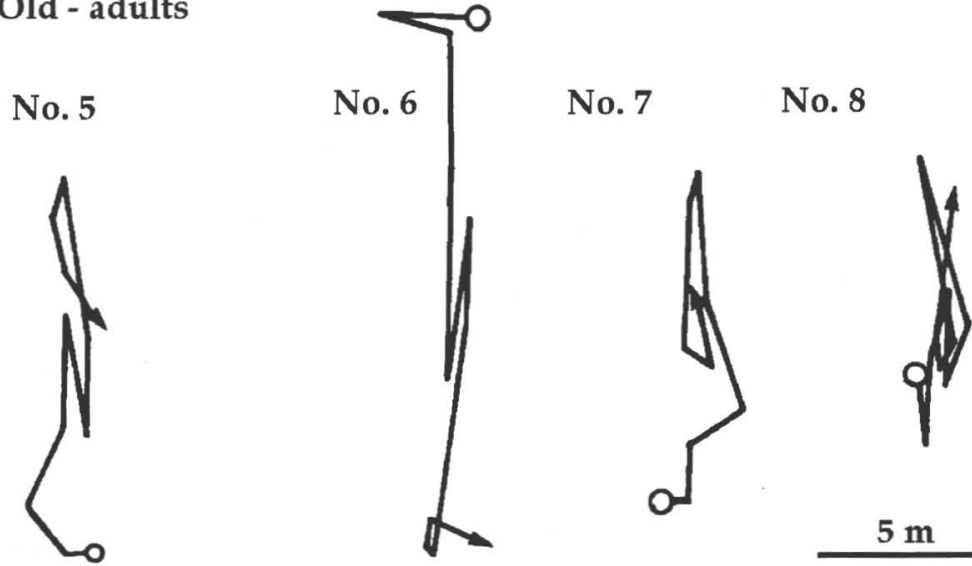

$5 \mathrm{~m}$

Fig. 2. Daily dispersals of radio-tagged snails 10 during a period of days (16 to $26 \mathrm{July}$, 1989) in shrubs along a road on Chihi-jima Island. Individuals No.1 to 4 are young adults, and No.5 to 8 are old adults.

The distribution of snail densities across the area at 13:00 on a very dry day, 19 July, 1987 was similar to that at 13:00, 5 July, 1987 (Figs. 1C and 1A).

On 21 July, two days after rain, the density distribution was concentrated in the grass area (Fig. 1D). These results suggest that the weather affects the patterns of their daily changes of microdistribution and habitat use. 


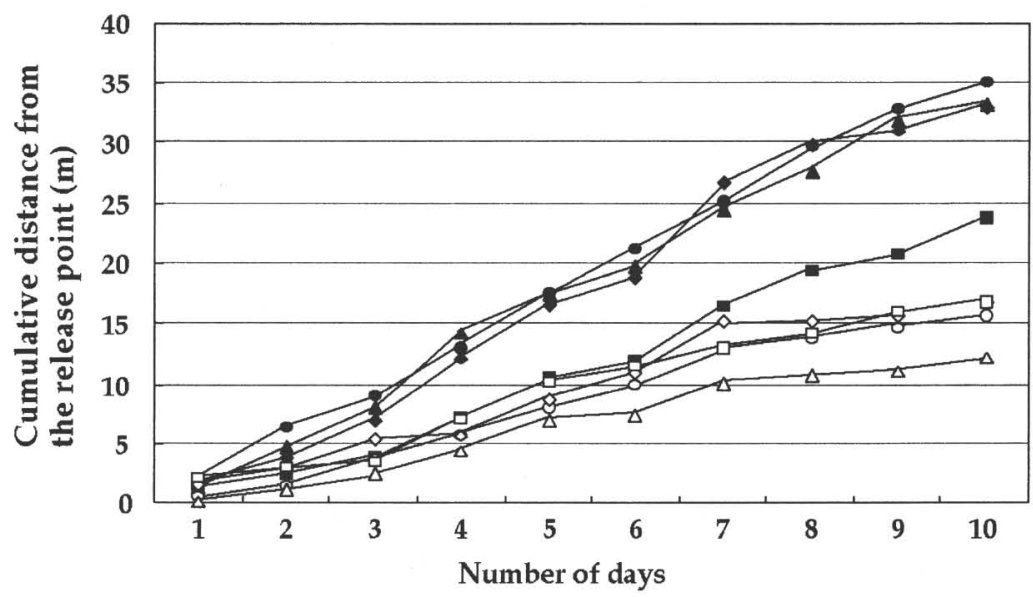

Fig. 3. Cumulative distances of dispersal of radio-tagged snails. Solid markers indicate young adults (No.1: ; No.2: $\square$; No3: $\boldsymbol{\Delta}$; No.4: $)$ ). Open markers indicate old adults (No.5: $\bigcirc$; No.6: $\square$; No.7: $\triangle$; No.8: $\diamond)$.

\section{Radio tracking}

Young adults and old adults differed in dispersal distance (Figs. 2 and 3). The cumulative distance of young adults $(31.9 \pm 4.02 ; \mathrm{M} \pm \mathrm{SD})$ was significantly longer than that of old adults $(16.25 \pm 3.51$; $\mathrm{M} \pm \mathrm{SD}$ ) (Mann-Whitney's $U$-test; $P=0.02$ ).

The resting sites of each snail were not fixed and changing parallel to the road but remained within shrub. Snails with radio-tags came out to the grass area every night. These patterns indicate that snails moved back and forth between the sites for resting and foraging. They were on the grass or the road at night and went back to their resting sites in the shrub just before sunrise.

\section{DISCUSSION}

A. fulica preferred shrubs for their resting. Shrubs are often along the road side. They are most abundant in the shrubs of Leucaena leucocephala, Ficus microcarpa, and Hernandia sonora on Chichi-jima. Such vegetation was also distributed in the areas around human residences and cultivated fields. On the other hand, A. fulica is hardly found in natural or secondary forests of Schima wallichii, Livistona chinensis var. boninensis, Pinus luchuensis or Casuarina equisetifolia.

The density of $A$. fulica along the road greatly changed at night and on rainy days, because snails crawled out to the grass and road. It suggests that they prefer open areas for foraging and mating. It would be one of reasons that $A$. fulica is a serious pest of field crops cultivated next to the forest.

Lake and O'Dowd (1991) reported that on Christmas Island, Indian Ocean, the endemic red crab Gecarcoidea natalis and A. fulica showed inverse patterns of abundance along the areas from disturbed habitats to intact rain forests. A. fulica was abundant in the disturbed habitat and rare in the adjacent rain forest, while red crabs were abundant in the rain forest but not in the disturbed habitat. When a sample of $A$. fulica was transplanted in the rain forest, $97 \%$ were killed by red crabs within 48 hours, while only $22 \%$ were killed when transplanted in the disturbed habitat. From these distribution 
patterns and predation experiments, they concluded that predation pressure by red clubs determined the distribution of $A$. fulica on Christmas Island.

However, in the Ogasawara Islands, $A$. fulica is relatively common in both natural and secondary forests. There are some predators of crabs (Metopograpsus messor, Geograpus grayi, Sesarma dehaani and Grapus strigosus) predate on A. fulica. But the distributions of these crabs are limited to areas around rivers and seashores. Snails are also eaten by the rodent Rattus rattus which mainly inhabits disturbed areas and is rare in forests. The forest bird, Tirudus dauma, preys upon A. fulica, but very rarely. The hermit crab, Coenobita purpreus may be the principal predator on $A$. fulica in the Ogasawara islands. It sometimes kills $A$. fulica to obtain the shell. This crab usually occurs in the coastal forests but not inland. Euglandina rosea was introduced as a natural enemy of Achatina to Chichi-jima Island from Hawaii in the 1960 's by the U.S. Navy. However, it only inhabits disturbed areas, and would not affect the abundance of $A$. fulica in forests in the Ogasawara Islands.

Aoki (1978) reported that the density of $A$. fulica is highest in areas disturbed by humans in the Ogasawara Islands. Numazawa et al. (1988) also found that this species is widely distributed in high density in such areas but relatively rare in natural forests in the Ogasawara Islands.

Tomiyama (1991) showed that the range of $A$. fulica is usually associated with the disturbed habitat. However, $A$. fulica is only observed around road-sides, cultivated fields, grass fields, and villages, but does not inhabit secondary forests. On the other hand most of the endemic land snail species of the Ogasawara Islands are inhabitants of natural forests (Tomiyama, 1991). These observations indicate that the range of $A$. fulica has been expanded with deforestation, while the endemic snails have been driven into the narrow area where natural forest remains.

ACKNOWLEDGEMENTS I thank the following persons. Takahiro Asami critically read earlier drafts of the manuscripts. Humio Hayashi, Noriko Tamura, Masatoshi Nakane and Shintarou Satou gave me many suggestions for the radio tracking. Kazuyoshi Miyashita provided the opportunity to investigate the giant African snail of the Ogasawara Islands. This study was partly supported by a grant-in-aid from the Ministry of Agriculture, Silviculture and Fisheries of Japan.

\section{REFERENCES}

Aoki, J. 1978. Investigations on soil fauna of the Bonin Islands II. Ecological distribution of the agate snail, Achatina fulica, and some possibilities of its ecological control. Edaphologia 18: 21-28.

Lake, P. S. \& O'Dowd, D.J. 1991. Red crabs in rain forest, Christmas Island: Biotic resistance to invasion by an exotic snail. Oikos 62: 25-29.

Mead, A. R. 1961. Giant African land snail. University of Chicago Press, Chicago.

1979. Economic Malacology with to Achatina fulica. Pulmonates 2B. Academic Press, London.

Muniappan, R., Duhamwl, G., Santiago, R. M. \& Acay, D. R. 1986. Giant African snail control in Bugsuk island, by Platydemus manokwari. Oleagineux 41: 183-188.

Numazawa, K., Koyano, S., Takeda, N. \& Takayanagi, H. 1988. Distribution and abundance of the giant African sanil, Achatina fulica (Ferussac) (Pulmonata; Achatinidae), in two islands, Chichijima and Haha-jima, of the Ogasawara (Bonin) Islands. Journal of Applied Entomology and 
Zoology, 32: 176-181.

Sturgeon, R. T. 1971. Achatina fulica infestation in Maiami, Florida. The Biologist 53: 93103.

Tomiyama, K. 1988. Giant African snail in Ogasawara Islands. Annual report of Ogasawara Research 11: $2-16$

— 1991. Terrestrial molluscan fauna of Chihchi-jima Islands, the Ogasawara Islands, with special reference to Ani-jima Island. Ogasawara Research 17\&18: 1-31.

- 1993. Growth and maturation pattern of giant African snail, Achatina fulica (Ferussac) (Stylommatophora; Achatinidae). Venus 52: 87-100.

Upatham, E. S., Kruatrachu, M. \& Baidikul, V. 1988. Cultivation of the giant African snail, Achatina fulica. Journal of Science Society of Thailand14: 25-40.

Received April 12, 1999

Accepted May 24, 2000

\section{冨山清升＜wide>北部太平洋島嶼におけるアフリカマイマイの休息場所周辺での日周行動}

森林周辺部におけるアフリカマイマイの日周行動の観察を行った。本種 乾燥した日に, 強い夜行性 の日周行動をとる。昼間の休息時の生息密度 林縁部のやぶで非常に高く, 森林内で 低い。本種を亜 成熟個体と完全成熟個体に分け，電波発信機を取り付けて追跡したところ，昼間の休息場所は，やは り林縁部に限られた。亜成熟個体の方が成熟個体よりもよく移動した。本種は, 夜間や雨天時の昼間 に，休息場所から開けた場所に移動して，摂食行動や配偶行動をとる。これらの行動様式は，畑地周 辺に潜んで夜間に農作物を食害するという熱帯・亜熱帯地域で見られる害虫としての本種の特性に一 致する。本種は自然林や 2 次林の林内にはほとんど生息せず，人為的に攪乱された場所を好むことか ら，攪乱地嗜好動物と言える。 